\title{
KEBIJAKAN HUKUM PIDANA DALAM TINDAK PIDANA KORUPSI PENGADAAN BARANG DAN JASA
}

\author{
Nisa Yulianingsih ${ }^{1}$, R.B. Sularto ${ }^{2}$
}

\begin{abstract}
Abstrak
Penelitian ini mengkaji mengenai kebijakan hukum pidana terutama kebijakan formulasi dalam menentukan arah kebijakan pengaturan tindak pidana korupsi pengadaan barang dan jasa di Indonesia saat ini dan masa yang akan datang. Kajian didasarkan pada hasil penelitian normatif untuk menemukan kaidah-kaidah dan norma-norma hukum dalam merumuskan tindak pidana korupsi pengadaan barang dan jasa. Hasil penelitian menyimpulkan bahwa pengaturan tindak pidana korupsi terutama dalam kegiatan barang dan jasa pengaturannya kurang efektif karena belum dirumuskan dan diformulasikan secara jelas mengenai sanksi yang dijatuhkan untuk pelaku tindak pidana korupsi dalam pengadaan barang dan jasa. Oleh karena itu, perlu adanya reformulasi mengenai pengaturan tindak pidana korupsi pengadaan barang dan jasa agar dapat mengakomodir pengaturan sanksi yang lebih tegas (pidana) atas pelanggaran proses pengadaan barang dan jasa.

Kata Kunci : Kebijakan Hukum Pidana, Tindak Pidana Korupsi, Pengadaan Barang dan Jasa

\section{A. Latar Belakang}

Pengadaan barang dan jasa pada hakikatnya merupakan upaya pihak

pengguna untuk mendapatkan atau mewujudkan barang dan jasa yang diinginkannya dengan menggunakan metode dan proses tertentu agar dicapai kesepakatan harga, waktu, dan kesempatan lainnya. ${ }^{3}$ Hakikat atau esensi pengadaan barang dan jasa tersebut dapat dilaksanakan sebaik-baiknya, apabila kedua belah pihak yaitu pihak pengguna dan penyedia selalu berpatokan pada filosofi pengadaan barang dan jasa, tunduk pada etika dan norma pengadaan barang dan jasa yang berlaku, mengikuti prinsip-prinsip, metode, dan proses pengadaan barang dan jasa yang baku.
\end{abstract}

\footnotetext{
${ }^{1}$ Mahasiswa Program Studi Magister IImu Hukum UNDIP

2 Dosen Program Studi Magister Ilmu Hukum UNDIP

${ }^{3}$ Adrian Sutedi, 2010, Aspek Hukum Pengadaan Barang dan J asa dan Berbagai Permasalahannya, Jakarta, Sinar Grafika, hlm 3.
} 
Namun, berbagai penyimpangan terjadi dalam proses pengadaan barang dan jasa pemerintah. Kerugian keuangan negara yang ditimbulkan akibat penyimpangan terhadap ketentuan pelaksanaan pengadaan barang dan jasa Pemerintah ternyata nilainya sangat besar, yang mengarah pada implikasi tindak pidana korupsi. Pembenahan konsep mengenai tindak pidana korupsi dalam kegiatan pengadaan barang dan jasa penting untuk menentukan arah kebijakan yang tepat agar tercapainya nilai keadilan, kemanfaatan dan sanksi hukum bagi para pelaku tindak pidana korupsi dalam kegiatan pengadaan barang dan jasa saat ini dan masa yang akan datang.

\section{B. Metode Penelitian}

Metode pendekatan yang digunakan dalam penelitian ini adalah pendekatan yuridis normatif untuk menemukan kaidah-kaidah dan normanorma hukum dalam merumuskan tindak pidana korupsi pengadaan barang dan jasa.

\section{Kerangka Teori}

Istilah policy dalam bahasa Inggris atau politiek dalam bahasa Belanda berarti kebijakan. Bertitik tolak dari kedua pengertian tersebut, maka istilah kebijakan hukum pidana dapat pula disebut dengan istilah politik hukum pidana. ${ }^{4}$ Pengertian kebijakan atau politik hukum pidana dapat dilihat dari politik hukum maupun dari politik kriminal. Masalah pokok kebijakan hukum pidana biasanya adalah masalah kebijakan kriminalisasi. Kriminalisasi adalah suatu kebijakan menetapkan suatu perbuatan yang semula bukan tindak pidana

\footnotetext{
${ }^{4}$ Barda Nawawi Arief, Bunga Rampai Kebijakan Hukum Pidana : Perkembangan Penyusunan Konsep KUHP Baru, Jakarta, Kencana, 2010, hlm.26.
} 
(tidak dipidana) menjadi suatu tindak pidana (perbuatan yang dapat dipidana). ${ }^{5}$ Kriminalisasi dalam hal ini tidak hanya diartikan sebagai proses untuk menjadikan suatu perbuatan menjadi tindak pidana, tetapi juga merupakan suatu kebijakan untuk menggunakan hukum pidana sebagai sarana untuk menanggulangi tindak pidana. ${ }^{6}$

Menurut Barda Nawawi Arief, kebijakan penegakan hukum pidana merupakan serangkaian proses yang terdiri dari tiga tahap kebijakan. Pertama, tahap kebijakan formulatif atau tahap kebijakan legislatif, yaitu tahap penyusunan/perumusan hukum pidana. Kedua, tahap kebijakan yudikatif/aplikatif, yaitu tahap penerapan hukum pidana. Ketiga, tahap kebijakan eksekutif/administrasi, yaitu tahap pelaksanaan/eksekusi hukum pidana. ${ }^{7}$ Dengan adanya tahap formulasi, maka upaya dalam mencegah dan menanggulangi kejahatan tidak hanya menjadi tugas dari aparatur penegak hukum, tetapi juga aparat pembuat hukum, karena kesalahan pada kebijakan legislatif menjadi kesalahan yang paling fatal yang dapat menjadi faktor penghambat upaya pencegahan dan penanggulangan kejahatan pada tahaptahap selanjutnya. Hal ini dikarenakan kebijakan legislatif merupakan tahapan paling strategis dari penal policy. ${ }^{8}$

Pengadaan barang dan jasa pada hakekatnya merupakan upaya untuk mendapatkan atau mewujudkan barang dan jasa yang diinginkan dengan

\footnotetext{
5 Barda Nawawi Arief, 2013, Kapita Selekta Hukum Pidana, Bandung, P.T Citra Aditya Bakti, hlm. 202.

${ }^{6}$ Muladi, 1995, Kapita Selekta Sistem Peradilan Pidana, Semarang, Badan Penerbit Universitas Diponegoro hIm. 39.

${ }^{7}$ Barda Nawawi Arief, Kebijakan Legislatif Dalam Penanggulangan Kejahatan Dengan Pidana Penjara, Yogyakarta, Genta Publishing, hlm.9.

8 Barda Nawawi Arief, 2007, Masalah Penegakan Hukum Dan Kebijakan Hukum Pidana Dalam Penanggulangan Kejahatan, Jakarta, Kencana Prenada Media Group, hlm.79.
} 
menggunakan metode dan proses tertentu untuk mencapai kesepakatan harga, waktu, dan kesepakatan lainnya. ${ }^{9}$ Pengaturan mengenai pengadaan barang dan jasa sebelumnya diatur di dalam Keputusan Presiden Nomor 18 Tahun 2000, yang kemudian dicabut dan digantikan dengan Keputusan Presiden Nomor 80 Tahun 2003, dicabut lagi dengan diterbitkannya Peraturan Presiden Nomor 54 Tahun 2010 tentang pengadaan barang/jasa. Setelah itu mengalami perubahan lagi menjadi Peraturan Presiden Nomor 35 Tahun 2011 tentang Perubahan atas Peraturan Presiden Nomor 54 Tahun 2010 tentang Pengadaan Barang/Jasa. Kemudian mengalami perubahan lagi menjadi Peraturan Presiden Nomor 70 Tahun 2012 tentang Perubahan Kedua atas Peraturan Presiden Nomor 54 Tahun 2010. Dalam peraturan Presiden Nomor 70 Tahun 2012 diatur pengertian pengadaan barang dan jasa yang tercantum dalam Pasal 1 point ke-1. Di dalam setiap tahapan proses pengadaan barang dan jasa, berbagai potensi pelanggaran dan penyimpangan terjadi dalam proses pengadaan barang dan jasa yang terkait dengan tidak pidana korupsi.

\section{Hasil dan Pembahasan}

\section{Pengaturan Kebijakan Formulasi Tindak Pidana Korupsi Pengadaan}

\section{Barang dan Jasa Saat Ini}

Pengaturan mengenai tindak pidana korupsi pengadaan barang dan jasa telah diatur dalam pasal-pasal KUHP, yaitu mengenai :

a. Penyuapan.

9 Indonesia, 2006, Prinsip Dasar Kebijakan dan Kerangka Hukum Pengadaan Barang dan Jasa, Jakarta, Indonesia Procurment Watch, hlm. 5. 
b. Perbuatan Curang.

c. Kejahatan Jabatan.

d. Pemerasan.

e. Penggunaan tanah negara.

f. Turut serta pemborong.

Selain itu, dalam Undang-Undang Nomor 31 Tahun 1999 dirumuskan beberapa perubahan dalam ancaman pidana bagi pelaku tindak pidana korupsi. Dalam undang-undang ini dikenal ancaman pidana mati sebagaimana tercantum dalam Pasal 2 ayat (2) yang bunyinya: "Dalam hal tindak pidana korupsi sebagaimana dimaksud dalam ayat (1) dilakukan dalam keadaan tertentu, pidana mati dapat dijatuhkan". Pengertian "keadaan tertentu" dalam ketentuan ini dimaksudkan sebagai pemberatan bagi pelaku tindak pidana korupsi apabila tindak pidana tersebut dilakukan pada waktu negara dalam keadaan bahaya sesuai dengan undang-undang yang berlaku, pada waktu terjadi bencana alam nasional, sebagai pengulangan tindak pidana korupsi, atau pada waktu negara dalam keadaan krisis ekonomi dan moneter.

Dengan adanya ancaman pidana mati ini, Undang-Undang Nomor 31 Tahun 1999 merupakan undang-undang yang paling keras dan berat di ASEAN. ${ }^{10}$ Namun, dalam perkembangannya, penjelasan ini dinyatakan tidak berlaku karena Undang-Undang Nomor 20 tahun 2001 tentang Perubahan Atas Undang-Undang Nomor 31 Tahun 1999 tentang

10 Surachmin dan Suhandi Cahaya, 2011, Strategi Dan Teknik Korupsi: Mengetahui Untuk Mencegah, Cetakan Kedua, Jakarta, Sinar Grafika, hlm. 73 
Pemberantasan Tindak Pidana Korupsi telah merumuskan baru penjelasan pasal tersebut. Perubahan ancaman pidana selain ancaman pidana mati adalah ancaman pidana minimum baik untuk pidana penjara ataupun denda. Konsep ancaman pidana minimum ini merupakan konsep baru yang tidak dikenal dalam KUHP.

Rumusan ancaman pidana minimum ini terdapat kekurangan, yakni tidak merumuskan pedoman pemidanaan untuk menerapkan ancaman pidana minimum ini. Seharusnya undang-undang khusus di luar KUHP membuat aturan tersendiri untuk penerapannya, karena ini merupakan konsekuensi logis dari Pasal 103 KUHP.

Tanpa adanya pedoman pemidanaan pidana minimal ini, maka tidak dapat ditentukan apakah pidana minimal dapat diperingan atau dapat diperberat. Kejanggalan lain nampak dalam pola pidana minimalnya. Ada delik yang diancam dengan pidana maksimalnya 20 tahun penjara dan pidana minimalnya pidana 4 tahun penjara seperti dalam Pasal 2 dan Pasal 12. Sedangkan, ada delik yang diancam dengan pidana maksimalnya 20 tahun penjara, namun ancaman pidana minimalnya 1 tahun penjara seperti pada Pasal 3. Delik lainnya diatur pidana minimal 1 tahun diancam dengan pidana maksimal 5 tahun penjara seperti pada Pasal 9 dan Pasal 11.

Konsep sistem perumusan kumulatif dan sistem perumusan kumulatif alternatif dalam ancaman pidana undang-undang ini yang dipergunakan tidaklah jelas karena konsep tersebut menimbulkan pertanyaan sederhana yang paling mendasar yakni mengapa delik korupsi 
berupa memperkaya diri dalam Pasal 2 diancam dengan pidana secara kumulatif, sedangkan menyalahgunakan kewenangan dalam Pasal 3 diancam dengan pidana secara kumulatif alternatif. Padahal kedua delik ini ancaman pidana maksimumnya sama dan bobot / kualitas deliknya juga sama.

Dapat disimpulkan bahwa pembentuk undang-undang masih belum tepat merumuskan sanksi pidana dalam tindak pidana korupsi sehingga wajar apabila pada era reformasi ini tindak pidana korupsi masih merajalela. Tidak terkendalinya perkembangan kriminalitas yang semakin meningkat, justru dapat disebabkan oleh tidak tepatnya jenis sanksi yang dipilih dan ditetapkan. Setidak-tidaknya perumusan pidana di dalam undang-undang yang kurang tepat dapat menjadi faktor timbul dan berkembangnya kriminalitas.

Pengaturan sanksi ada dalam Peraturan Presiden Nomor 70 Tahun 2012, terdapat di dalam Pasal 118 ayat (2) yaitu :

a. Sanksi administratif.

b. Sanksi pencantuman dalam daftar hitam.

c. Gugatan secara perdata.

d. Pelaporan secara pidana kepada pihak yang berwenang.

Berdasarkan rumusan sanksi yang terdapat dalam Perpres ini, maka tampaknya perumus ketentuan menganut teori konsekuensialis, yang menganggap suatu pemidanaan merupakan akibat perilaku yang menimbulkan kerugian, dan sudah selayaknya pelaku dikenakan suatu 
kerugian berupa penjatuhan sanksi pidana. Dalam pandangan ini, pencegahan kejahatan yang terjadi di masa yang akan datang merupakan tujuan utama pemidanaan. Dengan sanksi-sanksi yang dirumuskan, di mana pelaporan secara pidana menjadi jalan akhir tampak bahwa pembentuk aturan berpandangan bahwa pidana itu dapat membawa kebaikan karena dapat mencegah kejadian yang lebih buruk serta berpikir bahwa tidak ada alternatif lain yang setara baiknya dalam penanggulangan penyimpangan ini.

2. Kebijakan Hukum Pidana Perlindungan Saksi dan Korban di Indonesia Pada Masa Yang Akan Datang

Kebijakan formulasi Hukum Pidana dalam rangka penanggulangan tindak pidana korupsi yang akan datang sebenarnya telah diupayakan yaitu melalui penyusunan dalam Rancangan Undang-Undang Pemberantasan Tindak Pidana Korupsi (Konsep RUU Tipikor 2010). ${ }^{\mathbf{1 1}}$ Konsep RUU Pemberantasan Tindak Pidana Korupsi tersebut, merujuk pada Konvensi UNCAC 2003. Pada dasarnya, hampir semua ketentuan tindak pidana korupsi dan tindak pidana lain yang terkait dengan korupsi dalam RUU Pemberantasan Tipikor sama dengan UU Pemberantasan Tipikor.

Dari 17 bentuk tindak pidana korupsi yang diatur dalam Pasal 2Pasal 13 UU Pemberantasan Tipikor terdapat 3 (tiga) jenis tindak

$11<$ Tanpa Nama>, <Tanpa Judul>, <http://reformasihukum.org/file/peraturan/RUTipikor>. 
pidana korupsi yang tidak lagi ditemukan pengaturannya, yaitu yang saat ini diatur dalam Pasal :

a. Korupsi terkait kerugian keuangan negara (perbuatan secara melawan hukum menguntungkan diri sendiri/orang lain yang dapat merugikan keuangan/perekonomian negara) (Pasal 2)

b. suap (aktif dan pasif) terhadap advokat ( Pasal 5 dan 12 huruf c)

c. Tindak pidana terkait gratifikasi (Pasal 11, 12B ayat 2, dan Pasal 13).

Sementara itu, RUU Pemberantasan Tipikor mengatur berberapa jenis tindak pidana baru yang belum diatur dalam UU Pemberantasan Tipikor sebagai tindak pidana korupsi, yaitu:

a. Suap terhadap pejabat publik asing atau organisasi internasional,

b. Suap terhadap pejabat di sektor swasta,

c. Suap terhadap pejabat yang menjalan kepentingan umum,

d. Suap di sektor olahraga,

e. Tindak pidana memperdagangkan pengaruh,

f. Tindak pidana illicit enrichment,

g. Tindak pidana terkait penggunaan Anggaran Pendapatan Belanja Negara/Daerah (APBN/APBD) yang tidak sesuai dengan peruntukannya,

h. Tindak pidana terkait pengadaan barang dan jasa.

Dari 8 jenis tindak pidana baru tersebut sebenarnya hanya suap terhadap pejabat publik asing atau organisasi internasional, tindak 
pidana memperdagangkan pengaruh dan illicit enrichment yang benarbenar baru, yang selama ini belum ditemukan padanannya, baik dalam UU Pemberantasan Tipikor maupun peraturan perundang-undangan lainnya. Suap disektor swasta, kepentingan umum, sektor olahraga telah diatur dalam UU Tindak Pidana Suap (UU No. 11 Tahun 1980), penggelapan di sektor swasta telah diatur dalam KUHP. Sementara untuk pidana terkait APBN/APBD maupun pengadaan barang dan jasa tercakup dalam Pasal 2 dan 3 UU Pemberantasan Tipikor, dengan kata lain kedua jenis tindak pidana ini hanyalah penspesifikasian dari kedua Pasal di UU Pemberantasan Tipikor.

Selain masuknya tindak pidana-tindak pidana baru, hal yang positif dari RUU ini yaitu perubahan ketentuan dalam Pasal 3 UU Pemberantasan Tipikor (penyalahgunaan wewenang) dimana unsur "yang dapat merugikan keuangan negara...dst" dihapuskan, sehingga cakupannya lebih luas dari Pasal 3 tersebut. Dengan ketentuan ini, maka penyalahgunaan kewenangan yang dipidana akan lebih luas lagi hingga mencakup kolusi dan nepotisme yang saat ini diatur dalam UU 28/1999 tentang Penyelenggaraan Negara yang Bersih dan Bebas Korupsi Kolusi dan Nepotisme.

Selain pengaturan di dalam RUU Tindak Pidana Korupsi 2010, diatur juga di dalam Buku II Konsep KUHP 2012, merumuskan tindak pidana korupsi dalam Bab XXXII mengenai tindak pidana korupsi, yaitu mengenai : 
a. Lingkup suap yang terdapat di dalam Pasal 680, Pasal 681, dan Pasal 682 RUU KUHP,

b. Lingkup Penyalahgunaan wewenang yang merugikan keuangan negara yang terdapat di dalam Pasal Pasal 683, Pasal 684, Pasal 685, Pasal 686, dan Pasal 687 RUU KUHP,

Pada bagian lain kategori sebagai tindak pidana korupsi, diatur pula dalam Buku II Konsep KUHP 2012 mengenai Tindak Pidana Jabatan yang diatur dalam BAB XXXI yang terdapat di dalam Pasal 655, Pasal 658, Pasal 659,Pasal 660 yang khusus mengatur mengenai Hakim yang menerima hadiah/gratifikasi, Pasal 662, Pasal 663, dan Pasal 664 RUU KUHP.

Melihat tantangan yang semakin berat dalam menanggulangi tindak pidana korupsi ke depan, sebaiknya menjadikan Konsep KUHP 2012 sebagai Kebijakan hukum pidana bagi pemberantasan tindak pidana korupsi yang akan datang, sehingga diharapkan menjawab kebutuhan hukum masyarakat dalam mengatasi tindak pidana korupsi. Di sisi lain bahwa Konsep KUHP 2012 merupakan hasil pemikiranpemikiran hukum yang didasarkan pada nilai-nilai budaya bangsa yang tentunya berbeda dengan kondisi KUHP yang saat ini berlaku.

\section{E. Simpulan}

Pengaturan mengenai Tindak Pidana korupsi pengadaan barang dan jasa di dalam KUHP dirumuskan juga di dalam Undang-Undang Tindak Pidana Korupsi saat ini. Namun, masih ada kelemahan yang terkandung di 
dalam UU Tipikor saat ini, salah satunya mengenai rumusan ancaman pidana minimum, yaitu tidak merumuskan pedoman pemidanaan untuk menerapkan ancaman pidana minimum ini. Seharusnya undang-undang khusus di luar KUHP membuat aturan tersendiri untuk penerapannya, karena ini merupakan konsekuensi logis dari Pasal 103 KUHP. Perumusan tindak pidana korupsi dengan ruang lingkup yang dirumuskan dalam Konsep KUHP 2012 tersebut sudah cukup memberikan daya tangkal atau penanggulangan terhadap tindak pidana korupsi terutama bagi para White collar Crime yang melibatkan pejabat negara, termasuk di dalamnya penegak hukum di masa mendatang. 


\section{Daftar Pustaka}

Indonesia, 2006, Prinsip Dasar Kebijakan dan Kerangka Hukum Pengadaan Barang dan Jasa, Jakarta: Indonesia Procurment Watch

Muladi, 1995, Kapita Selekta Sistem Peradilan Pidana, Semarang: Badan Penerbit Universitas Diponegoro

, 2007, Masalah Penegakan Hukum Dan Kebijakan Hukum Pidana Dalam Penanggulangan Kejahatan, Jakarta: Kencana Prenada Media Group.

, 2010, Bunga Rampai Kebijakan Hukum Pidana: Perkembangan Penyusunan Konsep KUHP Baru, Jakarta: Kencana

------------, 2010, Kebijakan Legislatif Dalam Penanggulangan Kejahatan Dengan Pidana Penjara, Yogyakarta: Genta Publishing

-------------,2013, Kapita Selekta Hukum Pidana, Bandung: P.T Citra Aditya Bakti

Surachmin dan Suhandi Cahaya, 2011, Strategi Dan Teknik Korupsi: Mengetahui Untuk Mencegah, Cetakan Kedua, Jakarta: Sinar Grafika

Sutedi, Adrian, 2010, Aspek Hukum Pengadaan Barang dan Jasa dan Berbagai Permasalahannya, Jakarta: Sinar Grafika

\section{Peraturan perundang-undangan:}

Undang-Undang Nomor 31 Tahun 1999 jo. Undang-Undang Nomor 20 Tahun 2001 Tentang Tindak Pidana Korupsi

Peraturan Presiden Nomor 70 Tahun 2012 Tentang Pengadaan Barang dan Jasa Pemerintah.

\section{Website:}

<Tanpa Nama>, <http://reformasihukum.org/file/peraturan/RUTipikor> 